\title{
The Electoral Poetics of James Scullin's Campaign against Alfred Deakin, 1906: Anticipating "Fusion"
}

\author{
LIAM BYRNE \\ School of Historical and Philosophical Studies, University of Melbourne
}

\begin{abstract}
In the 1906 federal election James Scullin, then an unknown grocer, challenged the sitting Prime Minister, Alfred Deakin, for his seat of Ballaarat. This article examines this important event in Scullin's under-researched life story to consider the "electoral poetics" of electioneering in the early federation. Scullin's challenge to Deakin prefigured the defining realignment of Australian politics to come, the "Fusion" of 1909, and is indicative of Labor's new self-conceptualisation as a potential government with a mission to fundamentally restructure Australian democracy. This article explores Scullin's work as an expositor of this mission, and its significance for his political life.
\end{abstract}

In the Federal Election of 1906 a brash young upstart named James Scullin challenged the Prime Minister of Australia, Alfred Deakin, for his seat of Ballaarat. ${ }^{1}$ Scullin was an unknown, not even a politician but a mere grocer. Deakin was one of the most imposing political figures of his age. He had been integral to the design of the Australian Federation. He had a record of office, often working with the Australian Labor Party (ALP), sponsoring legislation favoured by the labour movement. ${ }^{2}$ Yet, as the campaign for the election due to be held on 12 December 1906 began, Deakin found himself assailed by the energetic young grocer carrying Labor's banner. This was an analytically potent campaign. 1906 was the last election contested by the "three elevens" ${ }^{3}$ of Federation's first decade. Scullin's challenge to Deakin prefigured the defining realignment of Australian politics to come, the "Fusion" of 1909, and is indicative of Labor's new self-conceptualisation as a party of potential government with a mission to fundamentally restructure Australian democracy.

The 1906 election was a milestone in Scullin's life, marking the moment his political career began. Despite this, it has escaped sustained investigation. Scullin's only biographer, John Robertson, covers the basic details of the campaign in his 1974 work, J.H. Scullin, concluding that the "good impression" Scullin made "did his personal cause no harm". ${ }^{4}$ The moment is mentioned in biographies of Deakin, ${ }^{5}$ and at times in Labor Party histories, but more from a sense of novelty than with serious analytical intent. ${ }^{6}$ L.F. "Fin" Crisp and B.C. Atkinson wrote on future British Labour

\footnotetext{
${ }^{1}$ Ballaarat refers to the federal constituency, Ballarat as the city at its heart.

${ }^{2}$ Liberal and Labor had been considered by many, including by Deakin, to be natural allies: Judith Brett, Australian Liberals and the Moral Middle Class: From Alfred Deakin to John Howard (Cambridge, 2003), p.21.

3 "Three elevens" was Deakin's term for the three-sided electoral contests of this period.

${ }^{4}$ John Robertson, J.H. Scullin: A Political Biography (Nedlands, 1974), p.12.

5 J.A. La Nauze, Alfred Deakin: A Biography Vol. 2 (Carlton, 1965), pp.419-420, 431. Judith Brett, The Enigmatic Mr Deakin (Melbourne, 2017), pp.343-5. Walter Murdoch's sketch neglects it entirely: Walter Murdoch, Alfred Deakin: A Sketch by Walter Murdoch (Melbourne, 1999).

${ }^{6}$ For instance: Ross McMullin, The Light on the Hill: The Australian Labor Party 1891-1991 (Oxford, 1991), p.60; Frank Bongiorno, The People's Party: Victorian Labor and the Radical Tradition (Carlton, 1996), p.86; Colin Cleary, Ballarat Labor: From Miner Hesitancy to Golden Age (Epsom, 2007), pp.32, 149.
}

This is the author manuscript accepted for publication and has undergone full peer review but has not been through the copyediting, typesetting, pagination and proofreading process, which may lead to differences between this version and the Version of Record. Please cite this article as doi: 10.1111/ajph.12564 
Prime Minister (and renegade) Ramsay MacDonald's intervention into the campaign, during his tour of Australia, with little discussion of Scullin. ${ }^{7}$

This treatment (or lack thereof) reflects the broader neglect of Scullin's life story. From 1906 until his retirement in 1949 Scullin was a figure of stature and influence in the labour movement as a journalist, powerbroker, and Labor leader. ${ }^{8}$ For decades, Scullin played a crucial role in shaping Labor policy, and crafting its programme. Under his leadership of the party, the ALP was taken from the political wilderness and back into government for the first time since the conscription "split" of 1916. Elected on 12 October, within weeks his government was overwhelmed by the Great Depression. Scullin's perceived weakness and failure to navigate these tempestuous times marred his legacy. It has obscured the important contribution he made to the ALP, but also the national story as a key figure in the debates that defined the early federation. Even after his prime ministership Scullin remained an enduring influence, playing an important role as advisor and confidant to the wartime prime minister, and his successor, John Curtin. ${ }^{9}$ But this rich life story, and contribution to Australia, has been obscured by his crisis-ridden tenure in power. ${ }^{10}$ This article intends to go some small way towards addressing this neglect.

It also contributes to the emerging scholarship on electoral politics. As Frank Bongiorno noted, the history of electioneering in Australia remains a relatively underdeveloped area of study despite the symbolic richness of such events in the construction of political life and culture. ${ }^{11}$ Bongiorno's own work on electioneering in New England in the second half of the nineteenth century indicates the value of this perspective. ${ }^{12}$ Other works explore the rough-and-tumble of colonial politics in the forging of antipodean democracy, ${ }^{13}$ the development of electoral processes and institutions,${ }^{14}$ and the adaptation of foreign techniques of popular electoral appeal while "on the stump". ${ }^{15}$ A recent study has considered elections "that shaped Australia"

\footnotetext{
${ }^{7}$ L.F. Crisp and B.C. Atkinson, "Ramsay MacDonald, James Scullin and Alfred Deakin at Ballarat. Imperial Standards, 1906”, Australian Journal of Politics and History, Vol. 17, 1 (1971), pp.73-81. Brian McKinlay does discuss Scullin's later campaigns for Corangamite in his research note: Brian McKinlay, "Three Events of National Significance in the Corangamite Electorate, 1910-1918", Labour History, no. 16 (1969), pp.49-54.

${ }^{8}$ A story detailed in his only biographical treatment: Robertson, J.H. Scullin.

${ }^{9}$ Lloyd Ross, John Curtin: a Biography (South Melbourne, 1977), p.99.

${ }^{10}$ See Scullin's consistently poor rankings in the opinions of journalists and scholars: Paul Strangio, "Evaluating Prime-Ministerial Performance: The Australian Experience", in Paul Strangio, Paul 'T Hart and James Walter, eds, Understanding Prime-Ministerial Performance: Comparative Perspectives (Oxford, 2013), pp.264-288.

${ }^{11}$ Frank Bongiorno, "Electioneering in New England 1856-1889", Journal of the Royal Australian Historical Society, Vol. 93, 2 (2007), p.133.

${ }^{12}$ Ibid., pp.133-151.

${ }^{13}$ Terry Irving, The Southern Tree of Liberty: The Democratic Movement in New South Wales before 1856 (Sydney, 2006); Sean Scalmer, "Containing Contention: A Reinterpretation of Democratic Change and Electoral Reform in the Australian Colonies", Australian Historical Studies, Vol. 42 (2011), pp.337-356.

${ }^{14}$ Marian Sawer, "Inventing the Nation Through the Ballot Box", in Pierre Boyer, Linda Cardinal, and David Headon, eds, From Subjects to Citizens: A Hundred Years of Citizenship in Australia and Canada (Ottawa, 2004), pp.61-80.; Marian Simms, From the Hustings to Harbour Views: Electoral Institutions in New South Wales, 1856 - 2006 (Sydney, 2006); Michael Hogan, Lesley Muir, Hilary Golder, eds, The People's Choice: Electoral Politics in Colonial New South Wales (Sydney, 2007); M.M.H. Thompson, The Seeds of Democracy: Early Elections in Colonial New South Wales (Sydney, 2006).

${ }^{15}$ Sean Scalmer, On The Stump: Campaign Oratory and Democracy in the United States, Britain, and Australia (Philadelphia, 2017).
} 
(1906 not included). ${ }^{16}$ These are aggregate studies, with a collation of sources spanning across decades, rather than specific and detailed narratives of individual campaigns. Less work has been done on electioneering in the early Federation, with exceptions, such as the edited collection on 1901: The Forgotten Election. ${ }^{17}$

Though it began and ended with Deakin leading a minority government, 1906 was an eventful campaign, the last before the infamous "Fusion" in 1909 established the two-party system of Labor contra anti-Labor. The Fusion has tended to be read as the inevitable result of hardening class divisions, as the Liberals and conservatives unified around a common class allegiance against the rising proletarian tide. ${ }^{18}$ This narrative has been unpicked by more recent accounts, including Nick Dyrenfurth's examination of the substantial intellectual efforts required to hone the Labor mythology of Fusion as representative of the class struggle. ${ }^{19}$ The most substantial re-reading of the event is Judith Brett's consideration of Deakin's motivations for the new alliance. Brett outlines the substantial policy overlaps between Labor and the Liberals, arguing that it was Labor's organisational model which provided the greatest barrier to unity. Labor MPs were part of a broader movement which considered them to be its delegates, and enforced a series of controls over their actions to ensure their continued loyalty, including a party pledge to adhere to the will of the majority of the caucus and the decisions of Labor conferences. Brett insists that the Liberal convictions of independent thought and action prevented Labor and the Liberals being drawn into a closer alliance, paving the way for Fusion. ${ }^{20}$ It is a compelling account, but in its focus on Deakin's motivations it obviates the substantial differences in ideology and outlook that divided Labor from its Liberal allies, particularly in Victoria.

Scullin's challenge to Deakin prefigured this political realignment, signalling the major shift to come. In his influential reading of nineteenth century British political culture, Politics and the People, James Vernon outlined the significance of "electoral poetics". ${ }^{21}$ To Vernon, electoral campaigns "ritually followed a sequence of events which spoke to the disenfranchised as well as the electors and allowed both to voice their approval or disapproval of, not only the available candidate, but the whole edifice of official politics". 22 Nineteenth-century elections could be read, he argued, as "melodramatic text(s)", narratives through which "constituencies literally acted out the various generic plots of romance, comedy, tragedy, and irony". ${ }^{23}$

The 1906 campaign for Ballaarat was a melodramatic text, in which the rituals and techniques of the Federation's early electoral culture as it underwent this new and defining alignment can be adumbrated. Within the contest, the political forces of the day clashed through the personages of Deakin and Scullin, illuminating the democratic culture of the early Federation. Scullin embodied Labor's challenge to the inherited political order. Like Labor, Scullin was a youthful challenger to the founding fathers of Federation, claiming the loyalty of the working class as a newly-independent political

\footnotetext{
${ }^{16}$ Benjamin Jones, Frank Bongiorno, and John Uhr, eds, Elections Matter: Ten Federal Elections that Shaped Australia (Clayton, 2018). This includes a brief biography of Scullin in discussion of 1929: Alex Millmow, "The Patrician and the Orator", pp.52-54.

${ }^{17}$ Marian Simms, ed., 1901: The Forgotten Election (St Lucia, 2011).

${ }^{18}$ Brett, Australian Liberals, p.20; Nick Dyrenfurth, "'Vote down the conspiracy': Labor's View of Fusion", in Paul Strangio and Nick Dyrenfurth, eds, Confusion: The Making of the Two-Party System (Carlton, 2009), p.72.

${ }^{19}$ Dyrenfurth, "“Vote Down the Conspiracy", pp.70-108.

${ }^{20}$ Brett, Australian Liberals and the Moral Middle Class, pp.19-27.

${ }^{21}$ See Bongiorno's advocacy: "Electioneering in New England 1856-1889", p.134.

22 James Vernon, Politics and the People: A Study in English Political Culture, c.1815-1867 (Cambridge, 1993), p.80.

${ }^{23}$ Ibid.
} 
force, and articulating a starkly different vision for Australia's future to his political rivals. The poetics of his campaign also represented the particularly intransigent attitude towards political alliances found within the Victorian Labor Party, and its desire for Labor to assert itself as a force independent from its erstwhile political allies. Where else in the world but the "social laboratory" would the prime minister and the unknown grocer be thrown together on such equal terms in a ritual of competition, rhetorical thrust and counterthrust, the focus of their combat the party programmes of recently embittered allies, with the very shape of the nation's polity at stake?

\section{The Shape of Australian Politics in 1906}

The election held on 12 December 1906 would be the last in which the "three elevens" which dominated the first decade of Australian politics competed. ${ }^{24}$ These were years of complicated politicking, as the dominant colonial political forces adapted to the requirements of the new national framework. The political constellations were uncertain, with divisions between ideology (liberal/conservative/Labor) ${ }^{25}$ the interests of the newly-formed states, and policy priorities (protection/free trade), often unstable and cutting across and through the party formations.

At the heart of it all was Deakin, who succeeded Edmund Barton as Prime Minister in 1903. Going to the polls that year, Deakin's Liberal Protectionists were unable to secure a majority (no party would until the decade's end), and governed with the support of the ALP, led by Chris Watson. Opposed by the Free Traders under George Reid, and soon challenged by a faction of conservative protectionists within his own ranks, Deakin was able to maintain office only until 1904. As tended to be the case in this unstable time, it was the parliament, rather than the polls, which determined the new government. After reaching an impasse with Labor over the government's arbitration bill, Deakin, decrying the instability of the situation, resigned in favour of Watson's ALP. ${ }^{26}$

This was an epochal, though short-lived, administration; the first national workers' government in the world. Though Watson's administration did little to upset the social order, it was enough to stoke fears and outrage on the right of politics. This included the now familiar pattern of media opprobrium, right-wing populist mobilisation (particularly in the countryside), and political leaders seeking to seize upon the intemperate mood. ${ }^{27}$ Labor's pro-nationalisation bent stoked the ire of conservatives and free traders alike, facilitating the transformation of right-wing opinion around an explicitly anti-socialist agenda. George Reid sought to utilise this new mood. Cobbling together a loose alliance of his Free Traders and conservative protectionists, he marshalled the numbers to eject Labor from office after just four months. ${ }^{28}$

Reid's alliance (held together only by opposition to Labor-in-government) soon fell apart, and Deakin was able to resume office in mid-1905. ${ }^{29}$ The three-party system remained, as did all its instability. ${ }^{30}$ Traditionally cast as the natural allies of the

\footnotetext{
${ }^{24}$ Deakin quoted in Stuart Macintyre, “Alfred Deakin”, in Michelle Grattan, ed., Australian Prime Ministers (Sydney, [Revised edition] 2010), p.47.

${ }^{25}$ There was, for instance, a split between the liberal and conservative protectionists that ruptured into open breach for a period of time: P. Loveday, "The Federal Parties", in P. Loveday, A.W. Martin and R.S. Parker, eds, The Emergence of the Australian Party System (Sydney, 1977), p.383.

${ }^{26}$ Macintyre, "Alfred Deakin", p.47.

${ }^{27}$ Brett, Australian Liberals and the Moral Middle Class, pp.21-2; Paul Strangio, Neither Power Nor Glory: 100 Years of Political Labor in Victoria 1856-1956 (Carlton, 2012), p.64.

${ }^{28}$ Macintyre, "Alfred Deakin", p.48; Helen Irving, "Sir George Houston Reid", in Grattan, ed., Australian Prime Ministers, p.68.

${ }^{29}$ Irving, "Sir George Houston Reid", pp.68-71.

${ }^{30}$ Brett, Australian Liberals and the Moral Middle Class, pp.18-9.
} 
liberals (even if its own protection/free trade split caused tensions), Labor had generally sought to use its numbers to support, rather than form, government to extract policy concessions. But the Watson ministry had changed matters. With a renewed confidence in itself, and hostility to Deakin for his perceived complicity in the downfall of its first national government, ${ }^{31}$ Labor repudiated further alliance with liberals (against Watson's objections). ${ }^{32}$

Support for this separatism was particularly strong in Victoria. Traditionally, the Victorian labour movement had evinced the staunchest belief in a Liberal-Labor alliance, impeding the development of an independent Labor Party. ${ }^{33}$ By the turn of the century, however, Federation gave added impetus to the calls for Labor to establish a stable presence as an independent entity in the state. This call was particularly strong amongst the state's socialists, a force that grew in influence and credibility within the party due to the presence of Tom Mann, the British radical, who was appointed party organiser in 1902. The widely-held belief that Liberals had equivocated on the fate of (or even betrayed) striking railway workers in Victoria in 1903 entrenched the conviction that Labor should strike out on its own. ${ }^{34}$ Opposition to this perspective was strongest in the federal parliamentary party, setting the scene for a showdown over the question of alliances at Labor's 1905 federal conference. ${ }^{35}$ Such tensions, Paul Strangio has noted, "was one of the drivers of fusion". 36

These emerging tensions sharpened the contest for Ballaarat in 1906, where a candidate from each of the "elevens" nominated. Joseph Kirton represented the newly named "Anti-Socialist" Party led by Deakin's antagonist, George Reid. Chair of the Ballarat Water Commission, in 1906 Kirton was in a brief interregnum from representing the seat of Ballarat West in the Legislative Assembly, losing it in 1904 (to the socialist leader Harry Scott Bennett), and winning it again in 1907 (when Bennett declined to stand). A Minister without Office under the conservative premiership of William "Iceberg" Irvine, he had earned the opprobrium of the labour movement by opposing the railway strike of 1903 , labelling it a "rebellion". ${ }^{37}$

The second candidate was Deakin himself, anticipating a lacklustre local contest that would allow him to strut and fret upon the national stage as he campaigned for his party to continue in government. Eccentric and brilliant, Deakin was a leviathan of liberal politics, and one of the most significant figures in the shaping of the Federation. His oratory was "extraordinary", with "the compelling physical presence of a great actor and the stamina for long performances in which body, mind and voice worked in unison" ${ }^{38} \mathrm{He}$ combined these "rhetorical flights" with a precise command over policy. ${ }^{39}$ Warm and charming he was regarded as "Affable Alfred", even amongst his political rivals. ${ }^{40}$

\footnotetext{
${ }^{31}$ Dyrenfurth, “"Vote down the conspiracy", p.82.

32 There was a prolonged debate that led to this discussion, with socialists in Victoria being particularly prominent in opposing alliance: ibid., pp.82-7; Loveday, "The Federal Parties", pp.411, 421-3; Paul Strangio, “"an intensity of feeling such as I had never before witnessed"', in Paul Strangio and Nick Dyrenfurth, eds, Confusion: The Making of the Australian Two-Party System (Carlton, 2009), pp.147-8.

${ }^{33}$ Strangio, “'an intensity of feeling such as I had never before witnessed”", p.135.

${ }^{34}$ Ibid., pp.143-144.

${ }^{35}$ Ibid., pp. 148.

${ }^{36}$ Ibid., p. 147.

${ }^{37}$ Weston Bate, "Kirton, Joseph William", Australian Dictionary of Biography (ADB), accessed at $<$ http://adb.anu.edu.au/biography/kirton-joseph-william-6977>.

${ }^{38}$ Brett, The Enigmatic Mr Deakin, p.4.

${ }^{39}$ Macintyre, "Alfred Deakin", p.46.

${ }^{40}$ Ibid., p.46.
} 
The third contender was unknown beyond the confines of the ALP, the Catholic community, a debating club, and the locals who visited his grocery. But as a result of his efforts in carrying Labor's standard as he assailed the Prime Minister's own territory, he would find his name and his picture in newspapers crossing the continent.

\section{The End of the Affair: Deakin and Labor Independence}

Deakin opened the federal campaign at Ballarat's Festival Hall, a large Victorian-era venue with a capacity of seven-thousand on the banks of Yarrowee Creek. ${ }^{41}$ Deakin began by detailing the reasons for Reid's fall and his assumption of office. It was an incisive and forensic account delivered by the sitting prime minister, suitable for the decorum of his office. He pledged to continue his government's programme rather than offering any radical new proposals. He made clear that the priority for his administration would centre around the "fiscal question", and in particular, the expansion of protectionist policies, "the very core of the kernel of the principles of the party to which he belongs". ${ }^{42}$

Though this was not the most inspiring of appeals, it would not take much for Deakin's passion to awaken. Early Federation campaign culture was more formalised than in the colonial era, but Australian politics had retained its rambunctiousness. Mass meetings and large gatherings were a central component of campaigning, providing an opportunity to establish morale and momentum. ${ }^{43}$ But these occasions were ripe for public displeasure to manifest itself, and, potentially, for a candidature to be derailed by an unanticipated question, or verbal assault. ${ }^{44}$ Unless, that is, the candidate was quick-witted and prepared for the thrust-and-parry, as Deakin certainly was. "You're sitting on a fence" accused one interjector, and Deakin came to life. His was the "centre party", the prime minister proclaimed, the party of responsible government "between the freetrade reactionaries on one side, and the socialist extremists of the other". ${ }^{45}$ His contempt for Reid was palpable, but of particular note was the extent of his attack on Labor. Being careful to make clear his respect for Labor's Leader, "Mr. Watson", and Labor's parliamentary party, they were, he alleged, controlled by "the machine politics" of the labour movement. ${ }^{46}$ Labor's zealous organisation and its control over its parliamentary wing was a threat matched only by Reid's "programme of panic". Neither was suitable, he averred, to govern Australia. He appealed to his audience, not to "allow the liberal and protectionist policy to be crushed between these two great parties". ${ }^{47}$

Deakin spared no mention for his opponents in Ballaarat. He was not playing the part of a mere candidate. Instead, he was seeking to represent himself as the government incarnate, with command over issues, presenting a steady consistency to the electorate. In assailing the heartless Labor machine, Deakin was presenting the contest as one between liberal and Labor values, rather than concrete policies. With protection the major issue of the day, he insisted, it was the nature of the parties that would pursue it which divided Liberal Protectionist and Labor, and justified his administration. There was no need for Deakin to get into the mud with two little known

\footnotetext{
41 “Mr. Deakin's Policy”, Daily Telegraph, 18 October 1906, p.7; "Mr. Deakin's Policy”, Sydney Morning Herald, 18 October 1906, p.6; "Mr. Deakin At Ballarat", Australasian, 20 October 1906, p.35.

42 "Mr. Deakin's Manifesto", Ovens and Murray Advertiser, 20 October 1906, p.2.

${ }^{43}$ Bongiorno, "Electioneering in New England 1856-1889", p.138.

${ }^{44}$ Ibid.

45 "Mr. Deakin At Ballarat", Australasian, 20 October 1906, p.35.

${ }^{46}$ Ibid.

${ }^{47}$ Ibid.
} 
upstarts on a Quixotic quest to unseat him. But soon Deakin found Scullin unavoidable as he scrambled for votes against the unexpectedly effective challenger.

\section{Scullin Enters the Stage}

Scullin was born in the small town of Trawalla, forty-one kilometres west of Ballarat, in colonial Victoria, 1876. His mother, Ann, and his father, John, were both products of the Irish migration of the nineteenth century, hailing from Derry. Scullin came of age amidst the great depression of the 1890s, and his experience of economic uncertainty and deprivation honed his sense of injustice. ${ }^{48}$ As prosperity slowly returned Scullin found stable employment as a grocer, managing a small shop on Skipton Street in Ballarat's south.

Scullin left the formal education system as a young teen, but he left with his thirst for learning unquenched. The young autodidact sought out opportunities for selfimprovement (common with other labour leaders in this era), expanding his intellectual world through deep engagement with books, public lectures, and the contents of the newspaper stand. He was an ardent participant in the Catholic Young Men's Society, part of the Australian Natives Association, and a spirited competitor in the South Street Debating Society, where he learned to construct an argument intended to persuade a sceptical audience.

Scullin joined Victorian Labor in 1903 after witnessing a speech by the famed socialist radical, and, at the time, Labor organiser Tom Mann. ${ }^{49}$ By 1904 he was campaigning for Labor candidates, most notably Tom Carey. ${ }^{50}$ Scullin had come to know Carey through the South Street Society, and for anyone with intentions of a political career, Carey was a good man to know. Well-connected in Ballarat politics, Carey served in 1906 as Vice President of the Labor branch (and, later, on Victorian Labor's central executive).$^{51} \mathrm{He}$ was part of the powerful coterie of Victorian Australian Workers Union (AWU) leaders headquartered in Ballarat. The AWU was Australia's largest union, wielding great influence within Labor as a result, particularly in the countryside.

It is not entirely clear how Scullin was chosen as Labor's candidate, though his relationship with Carey was probably of assistance. ${ }^{52}$ It is known that his selection came over the objections of the Federal Labor Leader Chris Watson, who thought opposing Deakin a mistake (a belief Deakin shared) and advocated ongoing electoral immunity for Liberal candidates, indicating the breach between Victorian Labor and the federal party on the relationship with the Liberals (this refusal to provide immunity set the scene for Labor's later victory at the 1910 election). ${ }^{53}$ Scullin seized the opportunity. In this hectic three-month period, we can see Scullin's political outlook emerge, as he consistently and at great length articulated his worldview, outlining positions indicative of the political project he would pursue throughout his life. We also gain insight into his personality and character, how he comported himself, how he built relationships, how he spoke and acted in a time of great pressure and challenge. We see him act out the electoral poetics of this crucial contest, representing Victorian Labor's newfound zealotry for an independent ALP as a force for government, free of its traditional ties to the Liberals, as represented in their greatest figure, Alfred Deakin.

\section{Scullin and Labor's Programme}

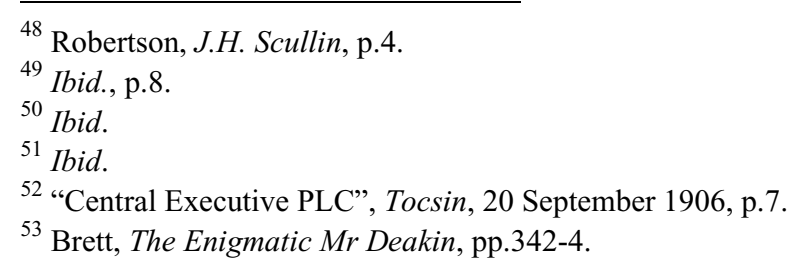


The 1906 campaign for Ballaarat was a "gentlemanly" affair. The fate of the new Federation (and its prime minister) was contested in a spirit of reason, rationality, and respectability. Though Labor was an insurgent party, and despite his own youth and outsider status, Scullin was determined to operate according to established rules and conventions. In this campaign, Scullin was claiming Labor's place as an independent force of potential government. The political melodrama of the Ballaarat election was to be conducted according to the rules of debate learned at South Street.

But, suffice to say, Scullin was not at South Street anymore. He was no longer competing for debating points, but for the cause of Labor, and his primary opponent was no eager young competitor, but the Prime Minister. Scullin seems to have been particularly aware of, and especially suitable for, his role as the expositor of Labor's programme. ${ }^{54}$ So he took to the stump. By the early twentieth century, the "stump" had evolved from its literal origins, but the centrality of mass oratory as a primary technique of politics and the drama of campaigning remained. Scullin's challenge was organised predominantly around mass electoral meetings (some more "mass" than others) in auditoriums, open spaces, and hastily assembled stages..$^{55}$ This was important for the poetics of his campaign. Scullin's appeals would be public performances, direct appeals from a candidate intending to persuade as Scullin expatiated at length upon Labor's programme, defending it from Deakin's detractions, and explaining what Labor alone could bring Australia. It allowed him, in other words, to speak directly to the constituency and explain why Labor had determined to strike out alone through the dramatic step of challenging the PM.

On a wet and windy evening at the end of October, Scullin launched his campaign to a mass gathering at Her Majesty's Theatre, a refined and spacious meeting place in Ballarat's heart. ${ }^{56}$ The meeting was chaired by Andrew McKissock, later a Labor senator, who was, at the time, president of the local Labor branch. ${ }^{57} \mathrm{He}$ was another AWU-connected powerbroker whose attention Scullin would attract in these months.

The meeting made the Melbourne news, with The Age reporting that Scullin spoke "at considerable length" in explanation of Labor's programme. ${ }^{58}$ This was an understatement. Scullin regularly lectured his audiences for anywhere between ninety minutes to two hours. ${ }^{59}$ Remarkably, he delivered this speech while suffering from a bout of "influenza" that had kept him bedridden for days. ${ }^{60}$ The conservative Argus newspaper succinctly summed up its reception of Scullin's appeal in the subheading: "socialist aims". ${ }^{61}$ As would so often be the case, Scullin's position of depth and nuance had been drastically simplified, and underestimated.

\footnotetext{
${ }^{54}$ Strangio, “'an intensity of feeling such as I had never before witnessed”, pp.134-161.

55 I note Bongiorno's reminder that much of the speech-as-performance is lost in such reports: "Electioneering in New England 1856-1889", p.138.

56 "Ballarat", The Age, 24 October 1906, p.8; "Federal Elections", Ballarat Star, 24 October 1906, p.2; "House of Representatives", Argus, 24 October 1906, p.8; "The Opposition to Mr. Deakin", Bendigo Independent, 24 October 1906, p.3; "The Socialist Objective", Argus, 25 October 1906, p.8; "The Fight for Ballarat", Worker, 1 November 1906, p.5.

${ }^{57}$ Kathleen Dermody, "McKissock, Andrew Nelson", Biographical Dictionary of the Australian Senate, accessed <http://biography.senate.gov.au/andrew-nelson-mckissock/>.

58 "Ballarat", Age, 24 October 1906, p.8.

59 "The Fight for Ballarat", Worker, 1 November 1906, p.5. Canvassing speeches of this length were a normalised part of campaigning culture: Bongiorno, "Electioneering in New England 1856-1889", p.138.

p.138.
60 "The Fight for Ballarat", Worker, 1 November 1906, p.5.

61 "House of Representatives", Argus, 24 October 1906, p.8; "The Socialist Objective", Argus, 25 October 1906, p.8.
} 
Scullin campaigned, he made clear, without malice or personal animosity towards Deakin or Kirton. He would not "speak ill of his opponents", even if he could, for both "were gentlemen". But the gentlemen were wrong in their estimation of Labor. Criticism of Kirton's anti-socialism was deemed too obvious, so instead, Scullin focused his analytical prowess on refuting Deakin, who had alleged that Labor was concentrated on the future to the detriment of the present needs of Australia, its programme devoid of practicalities in favour of "ideals". ${ }^{62}$ Scullin turned the logic on its head. While denying that Labor was a party of dreamers and absent-minded utopian schemers, he argued that governments "should look ahead". ${ }^{63}$ They should have a vision of the future they wished to achieve - this is what an objective was for. A government, Scullin asserted, was like a "father", who, revealing the gendered paternalism of his worldview, "looked into the future, and saw that his family was provided for when they grew up". Labor's objective was simple: Socialism. This firm commitment was much better, he argued, than the prime minister's vague promises.

But this was not a full-throated defence of the socialism advanced by Labor's radicals. All the party intended, he assured, was to secure for "all citizens the full results of their labour". Was there anything "ideal or visionary in that?" The Labor programme - what it intended to achieve in government through practical policies was separate from this objective. While the programme could be implemented, the "objective was not yet attainable". Scullin was arguing that while the party was guided by hopes of a faraway socialist future, its immediate aim was moderate reform. Socialism was a long-term process, resulting from the gradual implementation of collectivist policies through democratic mechanisms, while the citizenry was educated to its positive values.

This does not mean that Scullin failed to articulate a far-reaching vision of radical change. He assailed the status quo that saw a "few individuals" own "the means of production", ensuring the "unequal distribution" of wealth and resources. What was needed, he argued, echoing the objective Labor had adopted in 1905, was the nationalisation of monopolies (he later clarified that this would not be "confiscation", but based upon a "fair valuation"). ${ }^{64}$ This would be followed by a referendum to entrench protection as the official creed of the Commonwealth, and the implementation of the "new protection", under which the benefits of tariffs would be offered only to those employers who used the profits accrued to "pay good wages" and ensure "that the prices were fixed for the consumer". There should be, he argued, an amendment to the Arbitration Act that would allow for preference in state employment to be granted to trade unionists. With a particular passion he advocated a land tax on unimproved land values. ${ }^{65}$

This was not the socialist commonwealth, but neither was it the liberalism to which the Victorian labour movement had previously clung. ${ }^{66}$ Scullin refuted Deakin's claim that the decisive question of the election was protection, and its expansion. This was "not the real issue", and if the "people voted against any of the three men in the field they would not harm protection at all" ${ }^{67}$ Labor desired to settle protectionism "once

\footnotetext{
62 “Mr. Deakin's Policy”, Daily Telegraph, 18 October 1906, p.7.

63 "Federal Elections", Ballarat Star, 24 October 1906, p.2.

64 "The Ballarat Electorate", Ballarat Star, p.7 November 1906, p.6. For the debate over this objective and its adoption see: Australian Labor Party, Commonwealth Political Labour Conference 1905 (Brisbane, 1905), pp.10-14.

65 "Federal Elections", Ballarat Star, 24 October 1906, p.2.

${ }^{66}$ For liberal influences: Bongiorno, The People's Party, pp.5, 188-191. Some scholars have opposed this idea of a split with liberalism: Ian Tregenza, "Are We 'All Socialists Now'? New Liberalism, State Socialism and the Australian Settlement”, Labour History, no. 102 (2012), pp.87-98.

67 "Federal Elections", Ballarat Star, 24 October 1906, p.2.
} 
and for all" by holding a referendum that would put the issue before the people of Australia, rather than relying on negotiation between the commonwealth and states.

The performance did not end there. Question time was an important campaign ritual, through which eager audience members could intervene in the electoral process. One interrogator took the opportunity to quiz Scullin about the structures of the commonwealth. This was a time when the relationship between the levels of government remained unsettled. Though Deakin, of course, had great faith in the terms of Federation, which he had helped to write, Labor was more sceptical. ${ }^{68}$ The finelytuned constitutional arrangements had left a great deal of economic power in the hands of the states, particularly in areas of keen interest for Labor representatives: arbitration, protection, and the ability to control "trusts and combines". Often, the existence of conservative-dominated, non-elected Legislative Councils in the states provided an effective block upon progressive reform, diminishing the prospects of these major changes being introduced. For many Laborites such as Scullin (though often state MPs differed), this required a recalibration of the constitutional arrangement to readjust the balance of power, to allow far greater commonwealth intervention. The commonwealth government, Scullin argued, had to be empowered to govern for the nation without hindrance from parochial state interests, and it was up to the "people to say which party was to deal with those national questions". ${ }^{69}$

This meant, for Scullin, that the state parliaments "would eventually be abolished". ${ }^{70}$ This was not a simple repetition of Labor orthodoxy, but an indication of the bold and distinctive vision for Australia that the young man was developing. To unlock Australia's potential, a new constitutional order that would not hinder far-reaching change was required. He drew particular attention to the problem of land ownership, an issue he would continue to highlight in the years to come. ${ }^{71}$ Deakin, Scullin accused, was content that this "question should be left to the State Parliaments to be dealt with", whereas he believed in a bolder "tax on the unimproved values of land" to challenge the power of those who owned large tracts of rural Victoria as little more than sheep runs. $^{72}$

For Scullin, as for Labor more broadly, the system of referendum that the founders had installed as a potential outlet for change was not a democratic safety valve, to be used in case of emergency and unforeseen circumstances, but a mechanism to be enthusiastically deployed to recraft the terms of Federation. ${ }^{73}$ This, of course, went further for Scullin who believed that this process would lead to the ultimate abolition of the states themselves, a position he would continue to advocate. ${ }^{74}$ This was a project that would drive at the heart of the arrangements devised by Deakin. The upstart Laborites, not content with untethering themselves from the great man's munificent guidance, had the audacity to promise that, in government, they would strive to transform his greatest creation. The stakes of this election, and those to come,

\footnotetext{
${ }^{68}$ Labor mostly campaigned against the proposed constitution in the lead-up to Federation: Dyrenfurth, "“Vote down the conspiracy", p.73.

69 “'A Labor Rally", Ballarat Star, 27 November 1906, p.2.

70 "Federal Elections", Ballarat Star, 24 October 1906, p.2.

${ }^{71}$ See Commonwealth Parliamentary Debates, Vol.55, 45 (1 July 1910), pp.41-5.

72 “A Labor Rally”, Ballarat Star, 27 November 1906, p.2; “The Ballarat Electorate”, Ballarat Star, 7 November 1906, p.6.

${ }^{73}$ Helen Irving, To Constitute a Nation: A Cultural History of Australia's Constitution (Cambridge, 1999), p.151.

${ }^{74}$ ALP, Report of the Seventh Commonwealth Conference (Melbourne, 1918), p.18.
} 
concerned not just who would form government, but what type of government they would be empowered to lead, and the shape of Australia itself. ${ }^{75}$

\section{The Campaign Trail}

This was, of course, just one speech. It has been extracted here for extensive discursive analysis because of its symbolic meaning as the opening appeal of Scullin's campaign, its rebuttal of Deakin's claims to the electorate, for the richness of its content, and the detail of its reporting. Extensive consultation with the reports and records of Scullin's speeches throughout this three-month period demonstrates that the opening gambit provided the template for his subsequent performances.

At meeting after meeting across the electorate he further developed these points. Knowing that his chances were limited, Scullin took responsibility for dispelling myths perpetuated about Labor: how it organised, and what it believed. In elongated speeches he returned to these themes, explaining to crowds in Ballarat and the smaller townships what Labor stood for, elucidating the planks in its platform, and justifying its objective. $^{76}$

He extensively toured the electorate, with reports of his meetings emphasising these detailed explanations of Labor's programme. He spoke to three hundred in Mount Clear before trudging to Elaine to repeat the performance the next night. ${ }^{77}$ In Little Bendigo he followed his speech by asking if any present "could show a more progressive and more practical programme than was being offered to the electors of Australia" by Labor? None did. ${ }^{78}$ In an address in Newtown, the Ballarat Star reported that he had "dispelled the erroneous ideas which are held by many people with regard to the aims of the Labor Party" ${ }^{79}$ At the Rubicon Street Sunday School in Ballarat he was received "attentively" and thanked "amidst loud and prolonged cheers". ${ }^{80}$ The largest political meeting that had been held in the town of Buninyong "for years" saw Scullin address "the electors for an hour and a half, dealing with all the planks in the political platform of the Labor party". ${ }^{81}$

Such a tour reflected the nature of the electorate, based around the city of Ballarat, incorporating a number of smaller towns and large tracts of rural land. Scullin took to the stage, be it hastily erected or grandly adorned, to propound the cause of Labor. He demonstrated himself an adept and powerful interlocutor, perhaps not quite possessing Deakin's wit, but imprinting his own personality and perspective on his electoral appeals. Addressing a mass audience in East Ballarat, where Deakin had recently spoken, Scullin explained that the Prime Minister had exhorted his audience to look "at the score of practical measures his party had passed". Since then Scullin had, he assured his audience, "looked, and looked in vain [...] and he asked where were

\footnotetext{
75 During Andrew Fisher's later Labor government (1910-1913), two referenda would be initiated seeking to enlarge Commonwealth control, both were ardently opposed by Deakin: Mark Hearn, "Examined Suspiciously: Alfred Deakin, Eleanor Cameron and Australian Liberal Discourse in The 1911 Referendum", History Australia, Vol. 2, 3 (2005), pp.87.1-87.20.

76 "The Ballarat Electorate”, Ballarat Star, 7 November 1906, p.6; "Mr. J.H. Scullin's Candidature", Ballarat Star, 17 November 1906, p.1; "Mr. J. H. Scullin's Candidature”, Ballarat Star, 19 November 1906, p.1; "Ballarat Electorate", Ballarat Star, 21 November 1906, p.6; "Mr. Scullin's Candidature", Ballarat Star, 24 November 1906, p.1; "Mr. J. H. Scullin's Candidature", Ballarat Star, 26 November 1906, p.6; “A Labor Rally", Ballarat Star, 27 November 1906, p.2; "Mr. Scullin at Buninyong”, Ballarat Star, 28 November 1906, p.6; "Mr. Scullin's Candidature”, Ballarat Star, 8 December 1906, p.10; "Ballarat Electorate", Ballarat Star, 11 December 1906, p.1.

77 “Mr. J.H. Scullin's Candidature", Ballarat Star, 19 November 1906, p.1.

78 "Ballarat Electorate", Ballarat Star, 21 November 1906, p. 6.

79 “Mr. J.H. Scullin's Candidature", Ballarat Star, 17 November 1906, p.1.

80 “Mr. J.H. Scullin's Candidature", Ballarat Star, 26 November 1906, p.6.

81 "Mr. Scullin At Buninyong”, Ballarat Star, 28 November 1906, p.6.
} 
they?"; a question received with "Laughter". He would, he promised, "look again, and would use the microscope next time". 82

Scullin proved to be a thorn in Deakin's side. His persistence in refuting Deakin's claims and his calm advocacy for the Labor programme ensured that the Prime Minister could not take his seat for granted. ${ }^{83}$ One local supporter warned Deakin of Scullin's growing popularity in Ballarat, writing: "NNever since meetings at the Town Hall during the South African trouble have I witnessed such a one man sentiment." "\$4 In early December, just before the poll, the Argus was referring to the duel between them as "[o]ne of the keenest election fights in Victoria". ${ }^{85}$ As his party's greatest asset, Deakin was required to take to the hustings for other candidates in what was shaping as a tight national election. ${ }^{86}$ Even outside Ballarat, he could not escape Scullin's challenge. At one meeting at the Port Melbourne Town Hall, while campaigning for the Protectionist candidate, Deakin was greeted by stevedores "hooting". Upon commencing his speech, Deakin was interrupted by a call from the crowd for "three cheers for Scullin" which "were heartily given". An impassioned member of the crowd interjected midway into Deakin's speech, "Scullin's got you done", a heckle received with "Cheers and laughter". ${ }^{87}$

Labor's campaign for Ballaarat was biting. One satirical Punch cartoon had a tophatted Deakin trying to pull away from Labor, embodied as a leaping bulldog clinging to the back of his britches as the prime minister exclaimed: "Bless me! I thought the brute was a friend of mine [...] and now he means to get away with my seat". ${ }^{88}$ There was a perceptible change in tone in Scullin's campaign - a faint hope, that, perhaps, he could achieve the unprecedented and topple Deakin. ${ }^{89} \mathrm{He}$ was not the only one. In November Kirton announced that he was withdrawing from the campaign. ${ }^{90}$ There had been some concern amongst liberals and conservatives that the contest may split the anti-Labor vote, and provide an unanticipated boost for Scullin. Kirton's withdrawal was a relief for Deakin, ensuring there would be just one clear anti-Labor candidate. It was a portent of things to come.

Scullin received the news with good cheer. At a meeting in Little Bendigo he "welcomed a straight-out fight". ${ }^{91}$ Speaking in the Alfred Hall, where Deakin had launched his campaign, Scullin explained that there had been "a great change in the political arena", with one "gentleman" dropping out of the contest, having "fallen off a rail with a thud which had resounded throughout Australia". ${ }^{92}$ Scullin's response is indicative of Victorian Labor's changing estimation of the shape of Australian politics. Kirton's withdrawal had not altered the contest as there was, he argued, "no difference in their opposing forces". While Reid and his cronies advocated "anti-socialism" the "Deakin party" worked to "smooth the path for those engaged in private enterprise". ${ }^{93}$ This was an important statement, part of the broader repositioning that Labor was

\footnotetext{
82 "The Ballarat Electorate", Ballarat Star, 7 November 1906, p.6.

${ }^{83}$ Brett, The Enigmatic Mr Deakin, p.344.

${ }^{84}$ Quoted from ibid.

85 "Ballarat Election", Argus, 7 December 1906, p.5.

${ }^{86}$ This is not to suggest he neglected his electorate: "Mr. Deakin's Candidature", Ballarat Star, 14 November 1906, p.6; "Mr. Deakin's Meeting”, Age, 27 November 1906, p.8.

87 "Prime Minister Heckled", Argus, 28 November 1906, p.7.

88 "Deakin's Dilemma", Punch, 25 October 1906, p.7.

${ }^{89}$ Brett suggests that Deakin felt this was a possibility, Brett, The Enigmatic Mr Deakin, p.344.

90 “A Labor Rally”, Ballarat Star, 27 November 1906, p.2.

91 "Ballarat Electorate", Ballarat Star, 21 November 1906, p.6.

92 “A Labor Rally”, Ballarat Star, 27 November 1906, p.2.

${ }^{93}$ Ibid.
} 
undertaking. The ALP was no longer conceptualising itself as a radical usurper, nor as the tail that would wag the liberal dog. Instead, it was a potential government with its own distinctive vision for Australian democracy. Though forged, of course, through an array of influences, particularly Victorian liberalism, ${ }^{94}$ this was a worldview with its own tenor and place in Australia's polity.

Scullin's challenge to Deakin was part of this transition. The party enunciated a clear and distinctive programme for change, one based upon specific policies (some shared with liberals), but also a new conception of how Australian democracy should be shaped, and the constitution itself altered through mass acts of democracy to embed Labor's vision in the social order. As we have seen, Scullin had already repudiated the notion that protection, the issue that had done most to enforce the previous political divides and bind Victorian Labor to the liberals, was the core issue of the election. It was, instead, the larger vision Labor had of Australia's future that was at stake. Labour's voice in the state, the Labor Call, lost little time in affirming Scullin's conceptualisation. Without Kirton, it argued, the campaign had been simplified: "leaving the fight a clear-cut issue between Scullin for progress and Deakin for reaction". 95

In this sense, the campaign helped pre-empt and prompt the "Fusion" between Deakin's Liberal Protectionists with conservative protectionists and free traders in 1909. This would be a pivotal realignment in which ostensible opponents forged a new alliance based upon anti-Labor opposition. Core issues dividing Labor and non-Labor parties would come to the fore in the contest, in particular the crucial question of organisation and the relationship between parliamentarians and outside forces. But the broader visions of reform and the future direction for Australia and its democracy were already, in 1906, splitting Labor from its former allies. As Scullin's challenge indicates, Labor had already begun to redefine its place in the political firmament on these lines well before the Fusion.

In the end, despite the energy and enthusiasm of his campaign, Scullin was only able to poll 6,408 votes to Deakin's $12,900 .^{96}$ There was one more ritual for Scullin to complete: his concession speech, paying tribute to Deakin, who had "fought the contest honourably and fairly" ${ }^{97}$ But Scullin had much to be proud of in this campaign. He had carried Labor's banner with esteem and served its cause to acclaim. His name was known. He had demonstrated his ability to articulate a big-picture vision for Labor and Australia in front of figures of power and influence in the labour movement. His new political life had begun.

Scullin retained the reputation as the man who challenged Alfred Deakin throughout his career. ${ }^{98}$ The 1906 campaign brought him prominence, and connections, ensuring his contact with the powerful coterie of AWU men that facilitated his political rise. It is also indicative of the fundamental philosophy of Labor government that he retained through his life. In his terms as a Labor parliamentarian (1910-1913 and from 1922 until his retirement in 1949) he maintained the commitment articulated in 1906 to a new form of centralised democracy in which the strong Commonwealth government would utilise expanded powers to protect and enhance the social position of the working class. ${ }^{99}$ The bitter irony for Scullin, of course, was that, after spending the

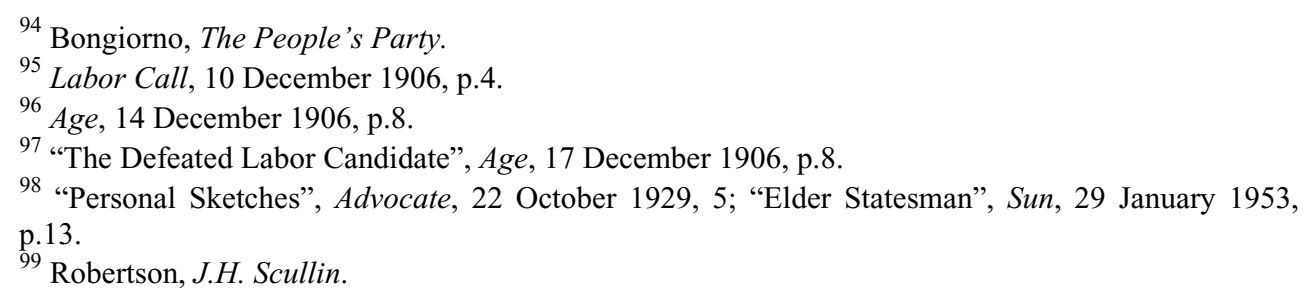


1920s warning of the looming economic crisis Australia was being exposed to by the Bruce government, he was fated to take power right as the Great Depression broke, overwhelming Australia's economy. ${ }^{100}$ Scullin has been poorly judged as a result, his place in history bound irrevocably with that troubled time. His career was not without success, however. A staunch advocate for uniform taxation that would remove the states' capacities to levy tax, Scullin was appointed by John Curtin onto the crucial committee to consider taxation during wartime in 1942. This was part of Curtin's ultimately successful manoeuvre to secure a federal income tax at the expense of the states. ${ }^{101}$ Scullin's was a long and winding career, of great triumphs, but also the most bitter of defeats. It all began with a young man, unafraid to tackle the big issues of the day, against no less than the Prime Minister himself.

\section{Conclusion}

This campaign alone did not set the terms of Labor's break with liberalism, nor singularly precipitate the "Fusion". Indeed, Labor would support Deakin in office until 1908, a fecund period of government in which many Labor-supported reforms that constituted the "Australian Settlement" were implemented. ${ }^{102}$ But the 1906 election had changed the national picture, at least beneath the surface. Once the issue of the tariff had been resolved, it became clear to Deakin that Labor would have little left to gain from the liberals, with an anti-Labor combination the most likely outcome. ${ }^{103}$

Brett is correct that there was overlap between the Liberals and Labor's federal leaders in key policy priorities. ${ }^{104}$ This was partially the result of electoral competition and the requirement to attract support for minority government. But focusing only on this level can limit an understanding of forces that precipitated the divide between Labor and Liberal-Protectionists, assisting in Fusion. As the electoral poetics of the 1906 campaign show, many in Labor, particularly Victorian Labor, believed that the time for independent government had come. Previously binding issues, such as protectionism, no longer held the same pertinence. Beneath policy confluence was a fundamental disagreement on the nature and extent of the further reforms that would need to be pursued for Australia to realise its potential. Labor was not content with the constitutional settlement and wished to pursue widespread changes to realise ambitious aims: a land tax, control of monopolies, and the extension of arbitration. It was an ambitious, and controversial, programme for reform, and one which required capable and persuasive expositors. Labor found one in 1906 in James Scullin.

The contest between Scullin and Deakin, in the mould of Vernon's "melodramatic texts", acted out the emerging breach between Labor and Deakin's Liberal Protectionists. This was not just a tactical differentiation, but one in which Labor pronounced its vision for Australia as one substantially different from the Liberals. The binding shibboleths of the past, most notably protection versus free trade, had been replaced by a new dichotomy: those who supported Labor's intentions for widescale reform, and those who opposed it. Progress versus reaction was the new conceptualisation of politics, and in his performances, Scullin encapsulated this burgeoning change. His careful explanations of Labor's programme were indicative of his forensic approach, but also of a party explaining and justifying its determination to strike out in its own unique direction.

\footnotetext{
${ }^{100}$ Ibid., pp.184-5.

${ }^{101}$ Ibid., pp.466-469.

${ }^{102}$ Brett, Australian Liberals and the Moral Middle Class, p.21.

${ }^{103}$ Loveday, "The Federal Parties", pp.424-5.

${ }^{104}$ Brett, Australian Liberals and the Moral Middle Class, p.23; Dyrenfurth, "Vote down the conspiracy"”, p.82.
} 
Bold and innovative, a mixture of personal perspective and Labor orthodoxy, the young man challenged the prime minister with an alternative vision of Australia's future. He propounded this vision through respectful but impassioned electoral appeals reflective of Labor's intervention into an established political culture: the candidate's public arguments, speeches, and debates backed by a largely invisible machine of campaigners and canvassers. The campaign of 1906 reveals much, and not least, the beginning of a journey obscured by a moment of extraordinary crisis and circumstance, but one that greatly contributed to the development of the politics of our country. Its electoral poetics speak of the great change to come, a redefinition in our country's political life. It deserves to be remembered. 


\section{University Library}

\section{- M M N E R VA A gateway to Melbourne's research publications}

Minerva Access is the Institutional Repository of The University of Melbourne

Author/s:

Byrne, L

Title:

The Electoral Poetics of James Scullin's Campaign against Alfred Deakin, 1906: Anticipating "Fusion"

Date:

2019-06-01

Citation:

Byrne, L. (2019). The Electoral Poetics of James Scullin's Campaign against Alfred Deakin, 1906: Anticipating "Fusion". AUSTRALIAN JOURNAL OF POLITICS AND HISTORY, 65 (2), pp.163-177. https://doi.org/10.1111/ajph.12564.

Persistent Link:

http://hdl.handle.net/11343/286860 